NASA/TM-2000-209891, Vol. 189

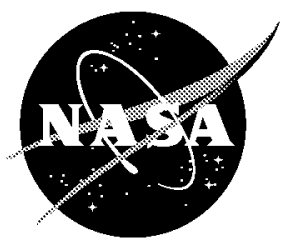

Technical Report Series on the Boreal Ecosystem-Atmosphere Study (BOREAS)

Forrest G. Hall and Karl Huemmrich, Editors

\title{
Volume 189
}

BOREAS TF-1 SSA-OA Tower Flux, Meteorological, and Soil Temperature

\section{Data}

T. Andrew Black, Z. Chen, and Zoran Nesic

University of British Columbia, Vancouver

National Aeronautics and

Space Administration

Goddard Space Flight Center

Greenbelt, Maryland 20771 
The NASA STI Program Office ... in Profile

Since its founding, NASA has been dedicated to the advancement of aeronautics and space science. The NASA Scientific and Technical Information (STI) Program Office plays a key part in helping NASA maintain this important role.

The NASA STI Program Office is operated by Langley Research Center, the lead center for NASA's scientific and technical information. The NASA STI Program Office provides access to the NASA STI Database, the largest collection of aeronautical and space science STI in the world. The Program Office is also NASA's institutional mechanism for disseminating the results of its research and development activities. These results are published by NASA in the NASA STI Report Series, which includes the following report types:

- TECHNICAL PUBLICATION. Reports of completed research or a major significant phase of research that present the results of NASA programs and include extensive data or theoretical analysis. Includes compilations of significant scientific and technical data and information deemed to be of continuing reference value. NASA's counterpart of peer-reviewed formal professional papers but has less stringent limitations on manuscript length and extent of graphic presentations.

- TECHNICAL MEMORANDUM. Scientific and technical findings that are preliminary or of specialized interest, e.g., quick release reports, working papers, and bibliographies that contain minimal annotation. Does not contain extensive analysis.

- CONTRACTOR REPORT. Scientific and technical findings by NASA-sponsored contractors and grantees.
- CONFERENCE PUBLICATION. Collected papers from scientific and technical conferences, symposia, seminars, or other meetings sponsored or cosponsored by NASA.

- SPECIAL PUBLICATION. Scientific, technical, or historical information from NASA programs, projects, and mission, often concerned with subjects having substantial public interest.

- TECHNICAL TRANSLATION. English-language translations of foreign scientific and technical material pertinent to NASA's mission.

Specialized services that complement the STI Program Office's diverse offerings include creating custom thesauri, building customized databases, organizing and publishing research results ... even providing videos.

For more information about the NASA STI Program Office, see the following:

- Access the NASA STI Program Home Page at http://www.sti.nasa.gov/STI-homepage.html

- E-mail your question via the Internet to help@sti.nasa.gov

- Fax your question to the NASA Access Help Desk at (301) 621-0134

- Telephone the NASA Access Help Desk at (301) 621-0390

- Write to:

NASA Access Help Desk

NASA Center for AeroSpace Information 7121 Standard Drive Hanover, MD 21076-1320 
NASA/TM-2000-209891, Vol. 189

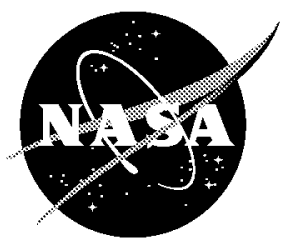

Technical Report Series on the Boreal Ecosystem-Atmosphere Study (BOREAS)

Forrest G. Hall and Karl Huemmrich, Editors

\section{Volume 189}

BOREAS TF-1 SSA-OA Tower Flux, Meteorological, and Soil Temperature

\section{Data}

T. Andrew Black, Z. Chen, and Zoran Nesic

University of British Columbia, Vancouver

National Aeronautics and

Space Administration

Goddard Space Flight Center

Greenbelt, Maryland 20771 


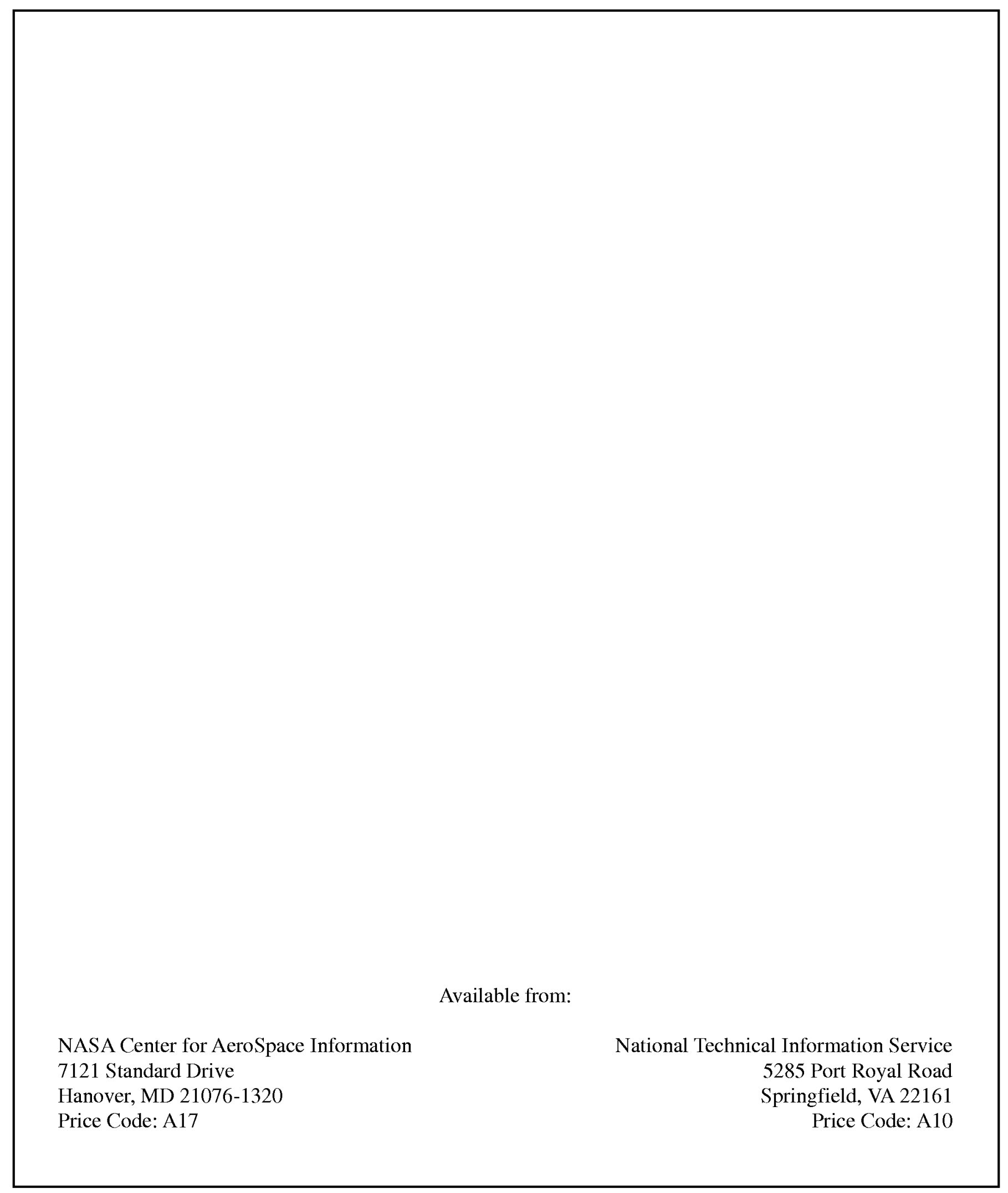




\title{
BOREAS TF-1 SSA-OA Tower Flux, Meteorological, and Soil Temperature Data
}

\author{
T. Andrew Black, Z. Chen, Zoran Nesic
}

\section{Summary}

The BOREAS TF-1 team collected energy, carbon dioxide, and momentum flux data above the canopy along with meteorological and soils data at the BOREAS SSA-OA site from mid-April to the end of the year for 1996. The data are available in tabular ASCII files.

\section{Table of Contents}

1) Data Set Overview

2) Investigator(s)

3) Theory of Measurements

4) Equipment

5) Data Acquisition Methods

6) Observations

7) Data Description

8) Data Organization

9) Data Manipulations

10) Errors

11) Notes

12) Application of the Data Set

13) Future Modifications and Plans

14) Software

15) Data Access

16) Output Products and Availability

17) References

18) Glossary of Terms

19) List of Acronyms

20) Document Information

\section{Data Set Overview}

\subsection{Data Set Identification}

BOREAS TF-01 SSA-OA Tower Flux, Meteorological, and Soil Temperature Data

\subsection{Data Set Introduction}

The Tower Flux (TF)-01 team collected heat, carbon dioxide, and momentum fluxes along with meteorological, soil temperature, soil moisture, and tree bole temperature data measured from the BOReal Ecosystem-Atmosphere Study (BOREAS) Southern Study Area (SSA) Old Aspen (OA) tower. These data were collected between 01-April and 31-December-1996. 


\subsection{Objective/Purpose}

The general objective was to study carbon dioxide and water vapor exchange between the forest and atmosphere at the SSA-OA site. Specific objectives were:

- To measure the fluxes of sensible heat, $\mathrm{H}_{2} \mathrm{O}$ and $\mathrm{CO}_{2}$ above the aspen stand throughout the year.

- To obtain from the $\mathrm{CO}_{2}$ flux data estimates of gross photosynthesis and respiration.

- To determine the contribution of the hazelnut understory to net ecosystem productivity (NEP).

- To determine the effects of environmental factors on stand evapotranspiration and NEP.

- To take part in the development of procedures for scaling up component fluxes to the stand level.

- To study the processes controlling turbulent transfer of $\mathrm{H}_{2} \mathrm{O}$ and $\mathrm{CO}_{2}$ within the stand.

- To take part in the evaluation of methods of estimating nocturnal $\mathrm{CO}_{2}$ in and above the stand.

\subsection{Summary of Parameters}

From the tower, above the canopy, the following variables were measured: latent heat flux, sensible heat flux, net radiation, $\mathrm{CO}_{2}$ flux, $\mathrm{CO}_{2}$ concentration, momentum flux, Bowen ratio, air temperature, wind speed and direction, friction velocity, incident and reflected photosynthetic photon flux density (PPFD), incident and reflected shortwave and longwave radiation, water vapor concentration, relative humidity, precipitation, and air pressure. Under the canopy, the following measurements were collected to describe the soil and forest: soil heat flux, soil temperature, soil water potential, soil water content, and tree bole temperatures.

\subsection{Discussion}

In 1993 and 1994, the TF-01 group measured fluxes under the canopy at the SSA-OA site, while the TF-02 group measured above-canopy fluxes and profiles at that site. In 1996, the TF-01 group moved its equipment to the top of the 39 meter tower to measure above-canopy fluxes; this document describes the 1996 data collection effort.

The fluxes of momentum, sensible heat, latent heat (water vapor), and carbon dioxide using the eddy correlation method were measured at $39 \mathrm{~m}$ height on the main flux tower beginning in April 1996. This system operated continuously through the rest of 1996. The eddy correlation system consisted of 3-dimensional sonic anemometer (model 1012R2A (Solent) Gill Instruments, Lymington, UK) with a $15 \mathrm{~cm}$ path length, an infrared gas $\left(\mathrm{CO}_{2} / \mathrm{H}_{2} \mathrm{O}\right)$ analyzer (IRGA) (model 6262, LI-COR, Inc., Lincoln, NE) and a krypton open-path hygrometer (model KH20, Campbell Scientific, Inc. (CSI), Logan, UT). Air was drawn at $8.0 \mathrm{~L} / \mathrm{min}$ down $3.2 \mathrm{~mm}$ inner diameter (i.d.) sampling tubing (model Bev-a-line, Thermoplastic Processes Inc., Sterling, NJ), then through copper tubing (3 mm i.d.) coiled and sandwiched between two aluminum plates within the same housing as the analyzer, and then through the analyzer's sample cell. To prevent condensation in the sampling tubing, it was heated $\left(2-3^{\circ} \mathrm{C}\right.$ above ambient) by passing an electric current through 20 -AWG nichrome wire (about $15 \mathrm{ohms}$ resistance) coiled around the exterior of the tubing. The pump (model DOA-V191-AA diaphragm pump, Gast Inc., Dayton, $\mathrm{OH}$ ) was located down stream of the sample cell resulting in the sample cell pressure being about $22 \mathrm{kPa}$ less than atmospheric pressure. The IRGA was operated in absolute mode with dry air at zero $\mathrm{CO}_{2}$ concentration flowing through the reference cell at $25 \mathrm{~cm}^{3} / \mathrm{min}$. The KH20 hygrometer was operated continuously to evaluate signal delay time and any attenuation resulting from the sample tubing (Leuning and King, 1992; Lee et al., 1994).

Supporting measurements included soil heat flux at the 3-cm depth measured using nine soil heat flux plates (two, model F, Middleton Instruments, Melbourne, Australia, and seven homemade, following Fuchs and Tanner (1968)) along a 20-m transect; average temperature of the surface $3 \mathrm{~cm}$ of the forest floor using two integrating thermometers; a soil temperature profile at depths of 2, 5, 10,20, 50 , and $100 \mathrm{~cm}$ (CSI direct-burial copper-constantan thermocouples); tree bole temperatures at 0.2, $4.0,8.0,12.0$, and $15.8 \mathrm{~cm}$ (thermocouple wire); downward total and diffuse solar (model PSP pyranometer, The Eppley Laboratory, Inc., Newport, RI), downward longwave (Eppley model PIR pyrgeometer), and net radiation (one model S-1 net radiometer, Swissteco Instruments, Oberriet, Switzerland (belonging to University of British Columbia (UBC)) and one Middleton model CN-1 net 
radiometer (belonging to Atmospheric Environment Service (AES)); PPFD (LI-COR model 190-SB quantum sensor) above the forest (at $33 \mathrm{~m}$ height from the ground ); wind speed and direction above the overstory (model 05031 vane propeller anemometer, R.M. Young Co., Traverse City, MI); soil water content using the time-domain reflectometry (TDR) technique (Hook and Livingston, 1996) with two probes consisting of 3 stainless steel rods ( $3 \mathrm{~mm}$ diameter, $30 \mathrm{~cm}$ long, and $2 \mathrm{~cm}$ apart) were positioned horizontally at $8 \mathrm{~cm}$ (organic layer) and $15 \mathrm{~cm}$ (mineral layer) depths, five $120 \mathrm{~cm}$ segmented rods (two thin stainless steel strips, $1.2 \mathrm{~cm}$ wide and $1.5 \mathrm{~cm}$ apart bonded by an epoxy resin layer) were installed to measure average water content in $15 \mathrm{~cm}(0-30 \mathrm{~cm})$ and $30 \mathrm{~cm}$ soil layers (30 - $120 \mathrm{~cm}$ depth); and infrared surface temperatures of the aspen and hazelnut canopies (model 4000 IR thermometer, Everest Interscience, Inc., Fullerton, CA).

\subsection{Related Data Sets}

BOREAS TF-01 SSA-OA Soil Characteristics Data

BOREAS TF-02 SSA-OA Tower Flux and Meteorological Data

BOREAS TF-01 Understory Flux, Meteorological, and Soil Temperature Data

BOREAS TF-09 SSA-OBS Tower Flux, Meteorological, and Soil Temperature Data

\section{Investigator(s)}

\subsection{Investigator Name and Title}

Prof. T. Andy Black

University of British Columbia

Department of Soil Science

\subsection{Title of Investigation}

Boreal Forest Atmosphere Interactions: Exchanges of Energy, Water Vapor and Trace Gases (SSA-OA)

\subsection{Contact Information}

\section{Contact 1:}

Mr. Zoran Nesic

University of British Columbia

Department of Soil Science

2357 Main Mall Rm. 139

Vancouver, BC V6T 1Z4 CANADA

(604) 822-3479, 822-5654 (Lab)

(604) 822-8639 (fax)

NESIC@PPC.UBC.CA

\section{Contact 2:}

Prof. T. Andy Black

University of British Columbia

Department of Soil Science

2357 Main Mall Rm. 139

Vancouver, BC V6T 1Z4 CANADA

(604) 822-2730

(604) 822-8639 (fax)

ablack@unixg.ubc.ca 


\section{Contact 3:}

K. Fred Huemmrich

University of Maryland

NASA GSFC

Code 923

Greenbelt, MD 20771

(301) 286-4862

(301) 286-0239 (fax)

Karl.Huemmrich@gsfc.nasa.gov

\section{Theory of Measurements}

Measurements of the fluxes of momentum, sensible heat, water vapor, and $\mathrm{CO}_{2}$ were made with the eddy covariance technique. Velocity components, air temperature, water vapor density, and $\mathrm{CO}_{2}$ concentration in the air were sampled rapidly, and calculations of relevant covariances were performed from these samples to obtain the fluxes. For example, the flux of $\mathrm{CO}_{2}$ was determined as follows:

$$
F_{c}=\overline{w^{\prime} c^{\prime}}
$$

where $w^{\prime}$ is the departure of the vertical velocity component from its mean over the averaging interval, usually 30 minute, and $c^{\prime}$ is the departure of $\mathrm{CO}_{2}$ concentration from its mean.

At the overstory level, three rotations in the coordinate transformation are applied to the flux data to make the lateral component $\left(v^{\prime}\right)$, vertical component $\left(w^{\prime}\right)$, and covariance $\left(\overline{u^{\prime} v^{\prime}}\right)$ of the wind vector equal to zero. At the understory level, however, only the mean lateral wind velocity component was rotated to zero under the suspicion that nonzero mean vertical velocities are possible within the trunk space. Webb, Pearman, and Leuning (1980) (WPL) corrections were made to the water vapor and carbon dioxide fluxes measured using the closed-path LI-COR 6262 infrared gas analyzer (IRGA). Broadening correction was done, but not on-line (see Chen et al., 1998, for summary of theory).

\section{Equipment}

\subsection{Sensor/Instrument Description}

\subsubsection{Collection Environment}

Measurements were collected from mid-April to the end of 1996. Over that time period, temperature conditions from less than $-30^{\circ} \mathrm{C}$ to over $30^{\circ} \mathrm{C}$ were experienced.

\subsubsection{Source/Platform}

A 37-m walk up scaffold main tower and a 6-m scaffold tower about $40 \mathrm{~m}$ from the main tower.

\subsubsection{Source/Platform Mission Objectives}

The objective of the flux tower was to support instrumentation for the study of the fluxes of $\mathrm{CO}_{2}$, energy, water vapor, and momentum between the forest and atmosphere at the SSA-OA.

\subsubsection{Key Variables}

Variables measured using eddy covariance: $\mathrm{CO}_{2}$ and water vapor fluxes, momentum fluxes, sensible heat fluxes, and latent heat fluxes.

Supporting meteorological variables: net radiation, downward total and diffuse solar radiation, downward longwave radiation, PPFD, wind speed, wind direction, air temperature, soil temperature, soil heat flux, soil moisture, and precipitation. 


\title{
4.1.5 Principles of Operation
}

A sonic anemometer determines the wind speed by a pair of transducers acting alternately as transmitters and receivers, sending pulses of high frequency ultrasound between themselves. The 3-D sonic has three pairs of transducers arranged in nonparallel axes.

The LI-COR $6262 \mathrm{CO}_{2} / \mathrm{H}_{2} \mathrm{O}$ analyzer is based on the difference in absorption of infrared radiation passing through two gas sampling cells. The reference cell is used for a gas of known $\mathrm{CO}_{2}$ or $\mathrm{H}_{2} \mathrm{O}$ concentration, and the sample cell is used for a gas of unknown concentration. Infrared radiation is transmitted through both cell paths, and the output of the analyzer is proportional to the difference in absorption between the two.

The principles of operation of most of the supporting instruments can be found in Pearcy et al. (1991) and Fritschen and Gay (1979).

\subsubsection{Sensor/Instrument Measurement Geometry}

Above-canopy sensors were supported by a vertical triangular mast mounted on top of a $37 \mathrm{~m}$ tall scaffold-type main tower. The sonic anemometer was mounted at a height of $39 \mathrm{~m}$. Other above-canopy measurements included downward total and diffuse solar (model PSP pyranometer, The Eppley Laboratory, Inc., Newport, RI), downward longwave (Eppley model PIR pyrgeometer) and net radiation (one model S-1 net radiometer, Swissteco Instruments, Oberriet, Switzerland, and one Middleton model CN-1 net radiometer), PPFD (LI-COR model 190-SB quantum sensor) above the forest (at $33 \mathrm{~m}$ height from the ground), wind speed and direction above the overstory (model 05031 vane propeller anemometer, R.M. Young Co., Traverse City, MI), and infrared surface temperatures of the aspen and hazelnut canopies (model 4000 IR thermometer, Everest Interscience, Inc., Fullerton, CA).

Under-canopy measurements included soil heat flux measured at the $3 \mathrm{~cm}$ depth using nine soil heat flux plates (two model F, Middleton Instruments, Melbourne, Australia, and seven homemade, following Fuchs and Tanner (1968)) along a $20 \mathrm{~m}$ transect, average temperature of the surface $3 \mathrm{~cm}$ of the forest floor using two integrating thermometers, a soil temperature profile at depths of 2, 5, 10, 20, 50 , and $100 \mathrm{~cm}$ (CSI direct-burial copper-constantan thermocouples); tree bole temperatures at 0.2 , $4.0,8.0,12.0$, and $15.8 \mathrm{~cm}$ into the bole (thermocouple wire); and soil water content using the time-domain reflectometry (TDR) technique (Hook and Livingston, 1996), where two probes consisting of 3 stainless steel roads ( $3 \mathrm{~mm}$ diameter, $30 \mathrm{~cm}$ long, and $2 \mathrm{~cm}$ apart) were positioned horizontally at $8-\mathrm{cm}$ (organic layer) and $15 \mathrm{~cm}$ (mineral layer) depths, and five $120 \mathrm{~cm}$ segmented rods (two thin stainless steel strips, $1.2 \mathrm{~cm}$ wide and $1.5 \mathrm{~cm}$ apart, bonded by an epoxy resin layer) were installed to measure average water content in $15-\mathrm{cm}(0-30 \mathrm{~cm})$ and $30 \mathrm{~cm}$ soil layers $(30-120 \mathrm{~cm}$ depth).

Tree bole temperatures were measured in aspen trees using thermocouples placed in the bole at several depths determined from the north side of the tree. The temperatures were measured at $3.12 \mathrm{~m}$ height for the $0.2 \mathrm{~cm}$ depth, $3.16 \mathrm{~m}$ height for the $4.0 \mathrm{~cm}$ depth, $3.18 \mathrm{~m}$ height for the $8.0 \mathrm{~cm}$ depth (the center of the bole), at $3.16 \mathrm{~m}$ height for the $12 \mathrm{~cm}$ depth ( $4 \mathrm{~cm}$ depth from south side), and at 3.12 $\mathrm{m}$ height for the $15.8 \mathrm{~cm}$ depth $(0.2 \mathrm{~cm}$ depth from south side). In addition, a measurement of the hazelnut stem temperature was made at $0.7 \mathrm{~m}$ height and $0.2 \mathrm{~cm}$ depth.

\author{
4.1.7 Manufacturer of Sensor/Instrument \\ Solent sonic anemometer: \\ Gill Instruments Limited \\ Solent House \\ Cannon Street \\ Lymington \\ Hmpshire \\ SO41 9BR \\ United Kingdom
}


DAT-310 sonic anemometer:

Kaijo-Denki Co., Ltd.

No 19.1 Chrome Kanda-Nishikicho

Chiyoda-Ku

Tokyo 101

Japan

LI-COR LI-6262 IRGA, 190-SB PPFD, and LAI-2000 PCA:

LI-COR Inc.

P.O. Box 4425/4421

Superior Street

Lincoln, NE 68504

(303) 499-1701

(303) 499-1767 (fax)

KH2O krypton hygrometer:

Campbell Scientific

P.O. Box 551

Logan, UT 84321

$\mathrm{CN}-1$ net radiometer:

Middleton Instruments, Inc.

P.O. Box 442

South Melbourne

Victoria, 3205

Australia

S-1 net radiometer:

Swissteco Instruments, Inc.

Stegweg, Eichenwies, CH-94633 OBERRIET SG

Switzerland

PSP pyranometer and PIR pyrgeometer:

The Eppley Laboratory, Inc.

12 Shefield Ave.

P.O. Box 419

Newport, RI 02840

(401) 847-1020

(401) 847-1031 (fax)

05031 vane propeller anemometer:

R.M. Young Co.

Traverse City, MI

Distributor:

Campbell Scientific

P.O. Box 551

Logan, UT 84321

(801) 753-234

(801) 752-3268 
Soil temperature (burial) Campbell Thermocouple, Copper-constantan thermocouple:

Campbell Scientific

P.O. Box 551

Logan, UT 84321

(801) 753-2342

(801) $752-3268$ (fax)

4000 IR thermometer:

Everest Interscience, Inc.

P.O. Box 3640

Fullerton, CA 92634-3640

(714) $992-4461$

M1 dewpoint hygrometer (with D2 sensor):

General Eastern Instruments Corp.

Watertown, MA

HMP-35C Vaisala humidity sensor:

Vaisala, Inc.

Woburn, MA

Distributor:

Campbell Scientific

P.O. Box 551

Logan, UT 84321

(801) 753-2342

(801) 752-3268 (fax)

Soil heat flux plate (model F):

Middleton Instruments, Inc.

P.O. Box 442

South Melbourne

Victoria, 3205

Australia

Time domain reflectometry (TDR):

G.S. Gabel Corp.

Victoria, BC, Canada

CS105 Barometer:

Vaisala, Inc.

Woburn, MA

Distributor:

Campbell Scientific

P.O. Box 551

Logan, UT 84321

(801) 753-2342

(801) 752-3268 (fax) 
TE525 Tipping-bucket rain gauge:

Texas Electronics

Distributor:

Campbell Scientific

P.O. Box 551

Logan, UT 84321

(801) 753-2342

(801) 752-3268 (fax)

Weighing rain gauge:

Belfort Instrument Co.

1600 S. Clinton Street

Baltimore, MD 21224

21x, CR10 Data logging system:

Campbell Scientific

P.O. Box 551

Logan, UT 84321

(801) 753-2342

(801) 752-3268 (fax)

TD-4X2N diaphragm pump:

Brailsford Co.

670 Milton Road

Rye, NY 10580

(914) 967-1820

(914) 967-1836 (fax)

DOA-V191-AA diaphragm pump:

Gast, Inc.

P.O. Box 97

Benton Harbor, MI

(616) 926-6171

(616) $925-8288$ (fax)

Bev-a-line tube:

Thermoplastic Processes, Inc.

Sterling NS

Dekoron tubing:

Wirex Controls Ltd.

9446 McLaughlin Road N. Unit \#27

Brampton, ON

Canada, L6X 4H9

(905) 459-0742

(905) 450-8216 


\subsection{Calibration}

\subsubsection{Specifications}

In 1996, the eddy covariance IRGA at the $33 \mathrm{~m}$ height was automatically calibrated by one of the eddy covariance PCs at midnight every day. A solenoid valve was opened, permitting nitrogen gas to flow into the entrance of the sampling tube for 12 seconds. This established the voltage signals corresponding to zero $\mathrm{CO}_{2}$ and water vapor concentrations. A second solenoid was then opened for 12 seconds, permitting dry air with $350 \mathrm{mmol} / \mathrm{mol} \mathrm{CO}_{2}$ to enter the sampling tube, thereby calibrating the analyzer. The computer changed the calibration parameters in the control program, which ensured that $\mathrm{CO}_{2}$ concentration was accurate to within $\pm 1 \mathrm{mmol} / \mathrm{mol}$.

\subsubsection{Tolerance}

See Section 4.2.1.

\subsubsection{Frequency of Calibration}

See Section 4.2.1.

\subsubsection{Other Calibration Information \\ None.}

\section{Data Acquisition Methods}

The eddy covariance system consisted of a 3-D sonic anemometer/thermometer (SOLENT 1012R2A) for detecting the three velocity components and air temperature, the latter being derived from the speed of sound following Kaimal and Gaynor (1991), an open-path $\mathrm{H}_{2} \mathrm{O}$ krypton gas analyzer for measuring water vapor density in the air, and a closed-path dual $\mathrm{H}_{2} \mathrm{O} / \mathrm{CO}_{2}$ IRGA (LI-COR 6262) for measuring water vapor density and $\mathrm{CO}_{2}$ concentration in the air.

The Solent sampled the wind speed components at $20.83 \mathrm{~Hz}$, and its analog-to digital converter sampled the LI-COR signals at $10 \mathrm{~Hz}$. Prior to sampling, the latter signals had been passed through a passive filter with a $7 \mathrm{~Hz}$ cut-off frequency. Spectral analysis showed that frequencies above $1 \mathrm{~Hz}$ made almost no contribution to fluxes.

For the flux system, all raw data were recorded using PC systems with backup tape drives. Half-hour fluxes were calculated online. For other measurements, all those data were recorded by data loggers (model 21X, Campbell Scientific, Inc., Logan, UT), which were networked together, using the model MD-9 network interface, along with the main system. Every 3 hours, this network automatically transferred (using PC ANYWHERE software, Symantec Corp.) all data from the loggers to a network computer. This computer was accessed from our laboratory at UBC through a communication system, which comprised a modem, cellular phone, and Yagi antenna at the site, and a phone and modem in the laboratory. The Yagi antenna was mounted above the trees, and the cellular phone was housed in a thermostatically controlled box near the antenna. At midnight, the site computer compressed the previous 24 hours of half-hour flux data, called the laboratory, and in 3 minutes transferred (using Kermit file transfer software) the compressed data to the laboratory computer.

\section{Observations}

\subsection{Data Notes}

None.

\subsection{Field Notes \\ None.}




\section{Data Description}

\subsection{Spatial Characteristics}

\subsubsection{Spatial Coverage}

All data were collected at the BOREAS SSA-OA site in the Prince Albert National Park (PANP). North American Datum of 1983 (NAD83) coordinates for the site are:

- SSA-OA: latitude $53.62889^{\circ} \mathrm{N}$, longitude $106.19779^{\circ} \mathrm{W}$, and elevation of $600.63 \mathrm{~m}$.

\subsubsection{Spatial Coverage Map}

Not applicable.

\subsubsection{Spatial Resolution}

Although the eddy covariance measurement is made at one point, it is well known that the fluxes measured with this technique can represent fluxes averaged over a relatively large area. An analysis of the upwind land surface area that contributes to a scalar flux measurement, often referred to as "fetch" or "footprint," is crucial in understanding the origins of the flux and any possible influences of spatial heterogeneity. According to Blanken's (1997) results (using Schuepp et al., 1990, model), the cumulative flux at $39 \mathrm{~m}$ reached $80 \%$ of the total flux at an upwind distance of $1,200 \mathrm{~m}$ under neutral conditions, $900 \mathrm{~m}$ under typical daytime stability conditions, and 2,700 $\mathrm{m}$ under typical nighttime stability conditions. The corresponding values for the $4 \mathrm{~m}$ height (above the understory) were 130, 80, and $300 \mathrm{~m}$. Baldocchi (1997) suggests the latter values are overestimates. . From the above results, there was adequate fetch at the $\mathrm{OA}$ site because the forest extended for at least $3 \mathrm{~km}$ in all directions.

\subsubsection{Projection}

None.

\subsubsection{Grid Description}

None.

\subsection{Temporal Characteristics}

\subsubsection{Temporal Coverage}

The flux data were collected from 20-April to 31-December-1996. The supporting meteorological data were collected from 02-February-1996 to 31-December-1996. Note that Saskatchewan Research Council (SRC) (Airborne Fluxes and Meteorology (AFM)-07) operated a MESONET site at the OA (70 $\mathrm{m}$ southeast of main tower) through the study period.

\subsubsection{Temporal Coverage Map}

None.

\subsubsection{Temporal Resolution}

The data reported are 30-minute statistical mean values.

\subsection{Data Characteristics}




\subsubsection{Parameter/Variable}

The parameters contained in the data files on the CD-ROM are:

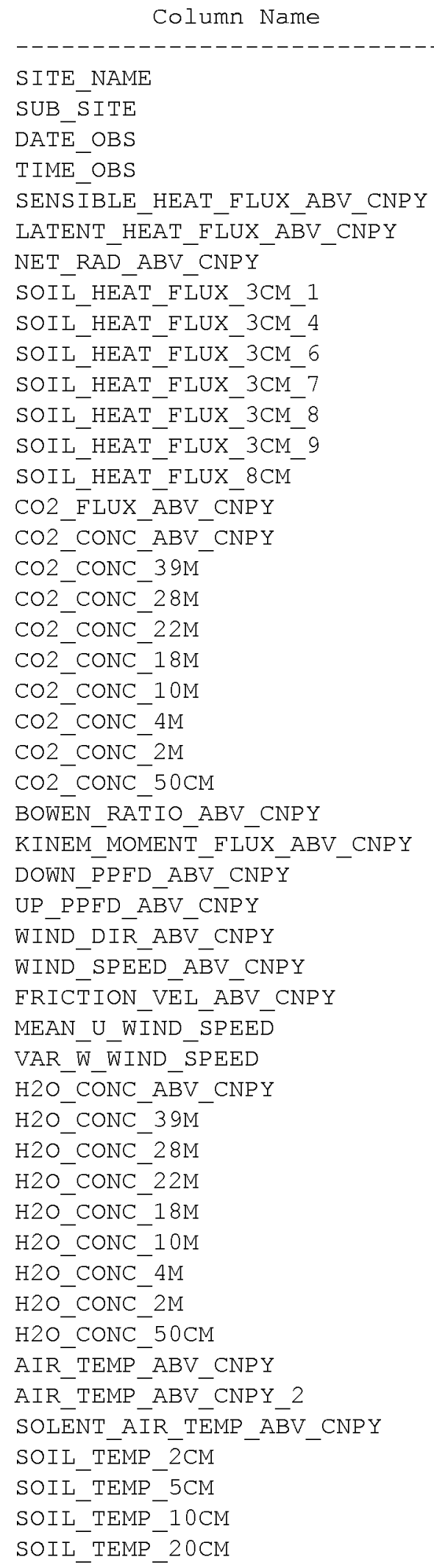




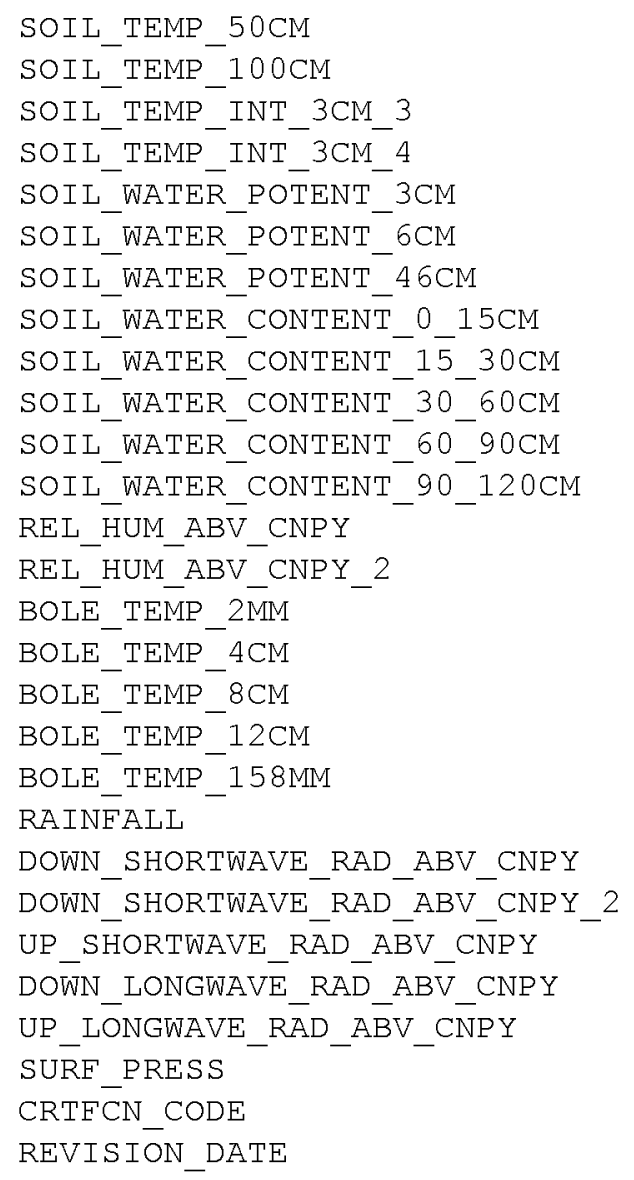

\subsubsection{Variable Description/Definition}

The descriptions of the parameters contained in the data files on the CD-ROM are:

\begin{tabular}{|c|c|}
\hline Column Name & Description \\
\hline-------- & ------------------------------------------------- \\
\hline SITE_NAME & $\begin{array}{l}\text { The identifier assigned to the site by BOREAS, } \\
\text { in the format SSS-TTT-CCCCC, where SSS identifies } \\
\text { the portion of the study area: NSA, SSA, REG, } \\
\text { TRN, and TTT identifies the cover type for the } \\
\text { site, } 999 \text { if unknown, and CCCCC is the identifier } \\
\text { for site, exactly what it means will vary with } \\
\text { site type. }\end{array}$ \\
\hline SUB_SITE & $\begin{array}{l}\text { The identifier assigned to the sub-site by BOREAS } \\
\text { in the format GGGGG-IIIII, where GGGGG is the } \\
\text { group associated with the sub-site instrument, } \\
\text { e.g. HYD06 or STAFF, and IIIII is the identifier } \\
\text { for sub-site, often this will refer to an } \\
\text { instrument. }\end{array}$ \\
\hline DATE_OBS & The date on which the data were collected. \\
\hline TIME_OBS & $\begin{array}{l}\text { The Greenwich Mean Time (GMT) of the start of the } \\
\text { data collection. }\end{array}$ \\
\hline SENSIBLE_HEAT_FLUX_ABV_CNPY & The sensible heat flux measured above the canopy. \\
\hline LATENT_HEAT_FLUX_ABV_CNPY & The latent heat flux measured above the canopy. \\
\hline NET_RAD_ABV_CNPY & The net radiation measured above the canopy. \\
\hline SOIL_HEAT_FLUX_3CM_1 & The soil heat flux \\
\hline
\end{tabular}




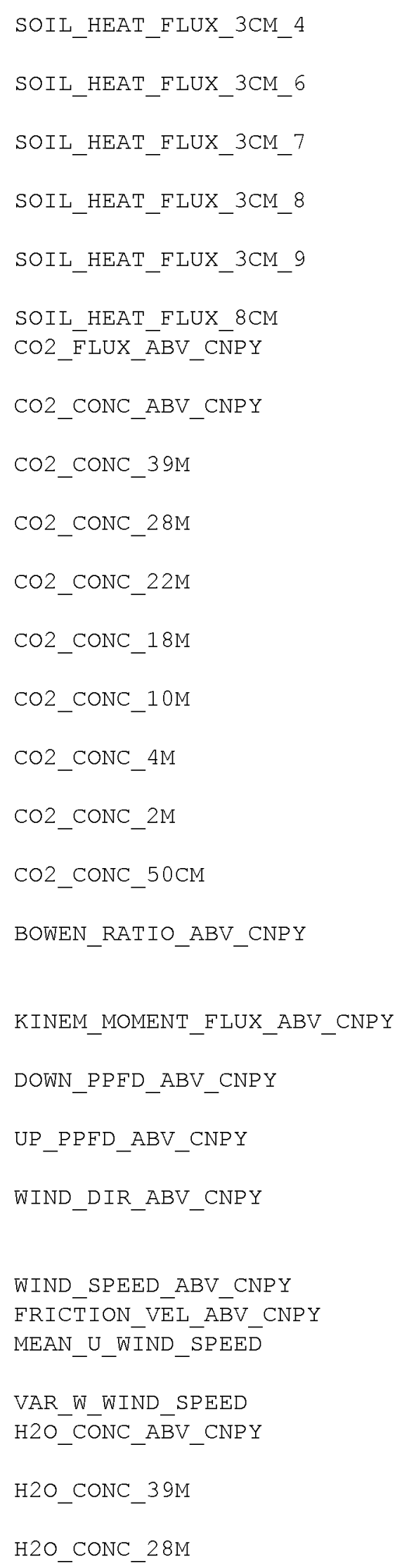

1 .

The soil heat flux measured at $3 \mathrm{~cm}$ depth at plot 4 .

The soil heat flux measured at $3 \mathrm{~cm}$ depth at plot 6 .

The soil heat flux measured at $3 \mathrm{~cm}$ depth at plot 7 .

The soil heat flux measured at $3 \mathrm{~cm}$ depth at plot 8 .

The soil heat flux measured at $3 \mathrm{~cm}$ depth at plot 9 .

The soil heat flux measured at $8 \mathrm{~cm}$ depth.

The carbon dioxide flux measured above the canopy .

The carbon dioxide concentration measured above the canopy.

The carbon dioxide concentration measured at 39 m above ground level.

The carbon dioxide concentration measured at 28 m above ground level.

The carbon dioxide concentration measured at 22 $m$ above ground level.

The carbon dioxide concentration measured at 18 m above ground level.

The carbon dioxide concentration measured at 10 m above ground level.

The carbon dioxide concentration measured at $4 \mathrm{~m}$ above ground level.

The carbon dioxide concentration measured at $2 \mathrm{~m}$ above ground level.

The carbon dioxide concentration measured at 50 $\mathrm{cm}$ above the ground.

The above-canopy Bowen Ratio, defined as the sensible heat flux divided by the latent heat flux.

Kinematic momentum flux density measured above the canopy.

The downward (incoming) photosynthetic photon flux density measured above the canopy.

The reflected photosynthetic photon flux density measured above the canopy.

The direction from which the wind is blowing (in creasing in a clockwise direction from the North) and measured above the canopy.

The wind speed measured above the canopy.

The friction velocity above the canopy.

Mean of a 30 minute period of the streamwise wind speed.

Variance of the vertical wind velocity.

The water vapor concentration measured above the canopy .

The water vapor concentration measured at $39 \mathrm{~m}$ above ground level.

The water vapor concentration measured at $28 \mathrm{~m}$

\section{Page 13}




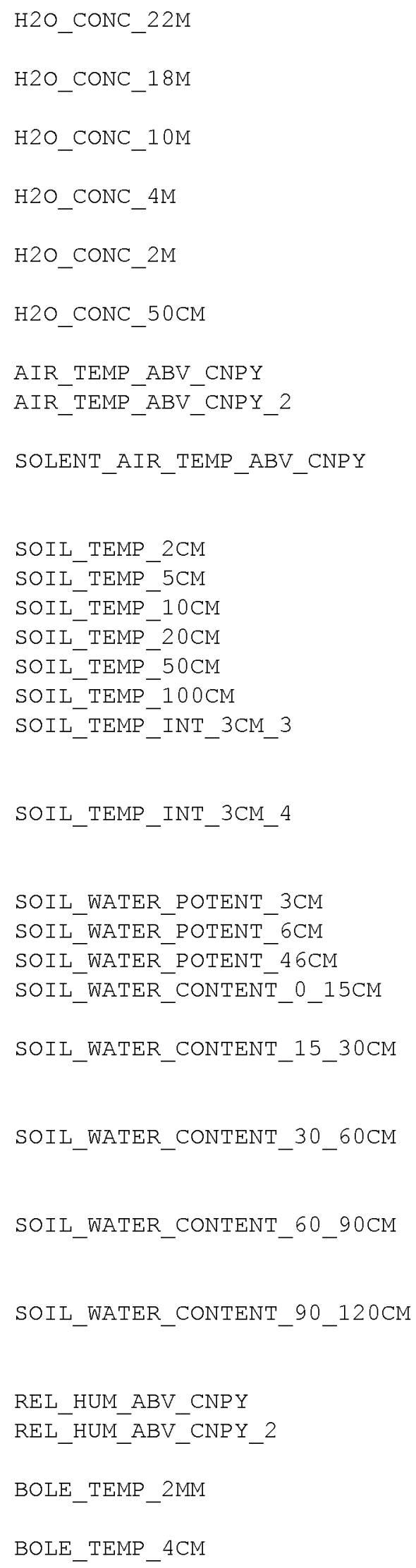

above ground level.

The water vapor concentration measured at $22 \mathrm{~m}$ above ground level.

The water vapor concentration measured at $18 \mathrm{~m}$ above ground level.

The water vapor concentration measured at $10 \mathrm{~m}$ above ground level.

The water vapor concentration measured at $4 \mathrm{~m}$ above ground level.

The water vapor concentration measured at $2 \mathrm{~m}$ above ground level.

The water vapor concentration measured at $50 \mathrm{~cm}$ above the ground.

The air temperature measured above the canopy.

A second air temperature measured above the canopy .

The air temperature measured by the solent sonic anemometer using the speed of sound

relationship.

Soil temperature at $2 \mathrm{~cm}$ depth.

soil temperature measured at a depth of $5 \mathrm{~cm}$.

Soil temperature at a depth of $10 \mathrm{~cm}$.

Soil temperature at $20 \mathrm{~cm}$ depth.

soil temperature measured at $50 \mathrm{~cm}$ depth.

The soil temperature recorded at $1 \mathrm{~m}$ in depth.

The temperature of the $0-3 \mathrm{~cm}$ surface layer

during the last 1 minute of the half hour from integrating thermometer 3 .

The temperature of the $0-3 \mathrm{~cm}$ surface layer

during the last 1 minute of the half hour from integrating thermometer 4 .

The soil water potential at $3 \mathrm{~cm}$ depth.

The soil water potential at $6 \mathrm{~cm}$ depth.

The soil water potential at $46 \mathrm{~cm}$ depth.

The soil water content between 0 and $15 \mathrm{~cm}$ depth, measured by Time Domain Reflectometry (TDR).

The soil water content between 15 and $30 \mathrm{~cm}$

depth, measured by Time Domain Reflectometry (TDR) .

The soil water content between 30 and $60 \mathrm{~cm}$ depth, measured by Time Domain Reflectometry (TDR).

The soil water content between 60 and $90 \mathrm{~cm}$ depth, measured by Time Domain Reflectometry (TDR).

The soil water content between 90 and $120 \mathrm{~cm}$ depth, measured by Time Domain Reflectometry (TDR) .

The relative humidity measured above the canopy. A second relative humidity measured above the canopy .

Tree bole temperature at $0.2 \mathrm{~cm}$ depth from north side.

Tree bole temperature at $4 \mathrm{~cm}$ depth from north

\section{Page 14}




BOLE_TEMP_ ${ }^{8 \mathrm{CM}}$
BOLE_TEMP_12CM
BOLE_TEMP_158MM
RAINEALL
DOWN_SHORTWAVE_RAD_ABV_CNPY
DOWN_SHORTWAVE_RAD_ABV_CNPY_2
UP_SHORTWAVE_RAD_ABV_CNPY
DOWN_LONGWAVE_RAD_ABV_CNPY
UP_LONGWAVE_RAD_ABV_CNPY
SURF_PRESS
CRTFCN_CODE

REVISION_DATE side.

Tree bole temperature at $8 \mathrm{~cm}$ depth from north side.

Tree bole temperature at $12 \mathrm{~cm}$ depth from north side.

Tree bole temperature at $15.8 \mathrm{~cm}$ depth from north side.

The amount of rainfall measured above the canopy over the 30 minute period.

The downward (incoming) solar radiation measured above the canopy.

A second downward (incoming) shortwave radiation measurement taken above the canopy.

The reflected (outgoing) solar radiation measured above the canopy.

The downward (incoming) longwave radiation measured above the canopy.

The upward (outgoing) longwave radiation measured above the canopy.

The atmospheric pressure measured at the station. The BOREAS certification level of the data.

Examples are CPI (Checked by PI), CGR (Certified by Group), PRE (Preliminary), and CPI-??? (CPI but questionable).

The most recent date when the information in the referenced data base table record was revised.

\subsubsection{Unit of Measurement}

The measurement units for the parameters contained in the data files on the CD-ROM are:

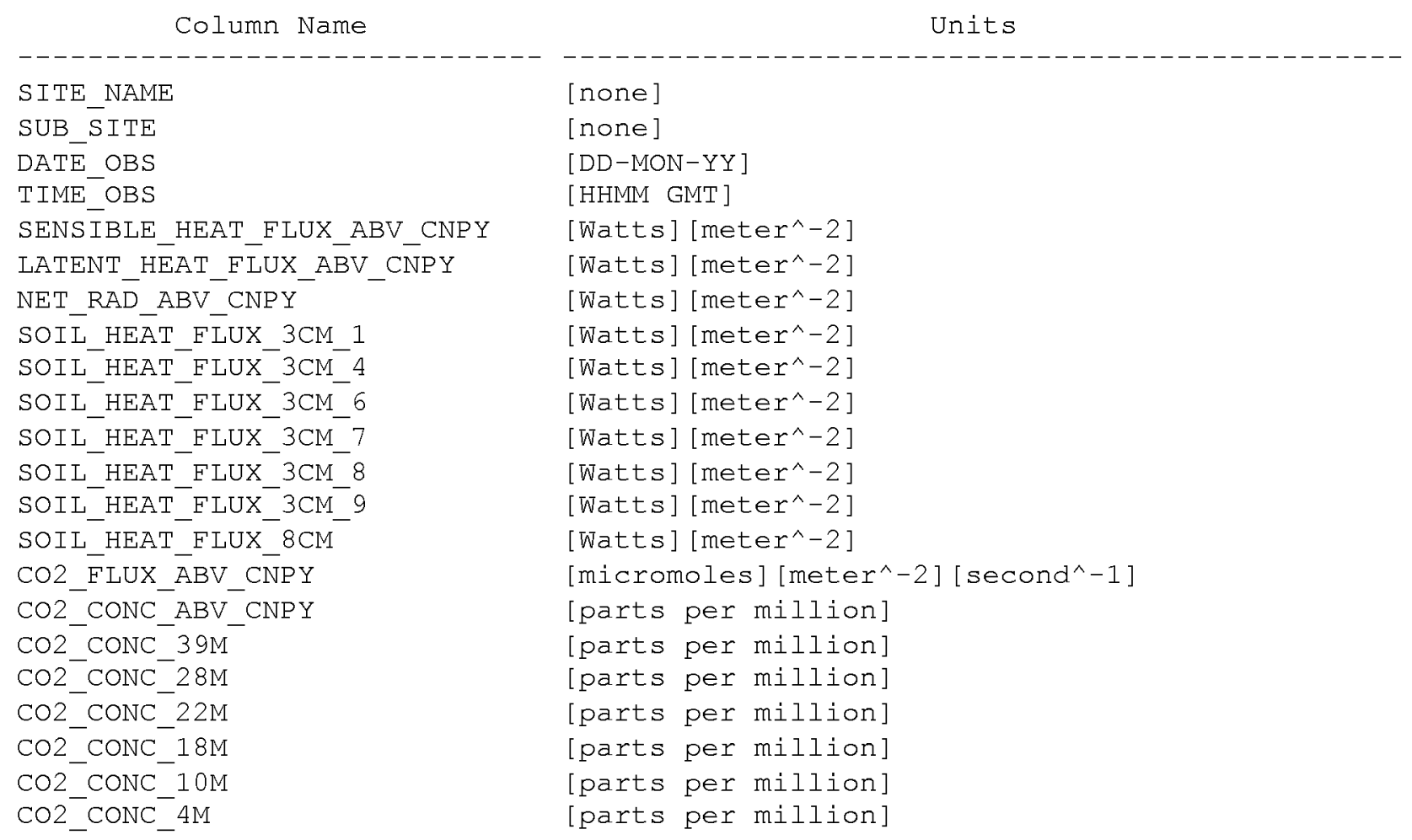




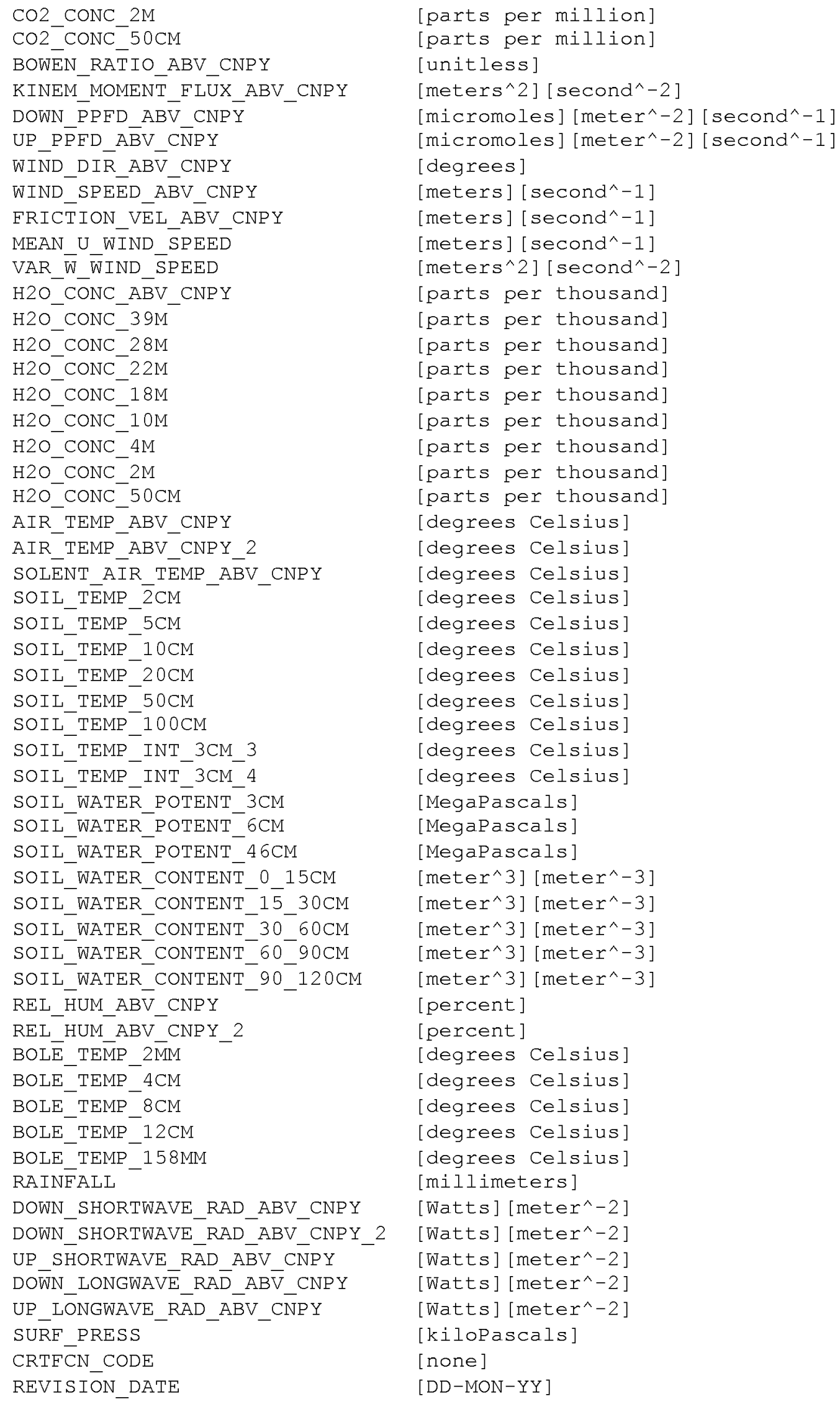




\subsubsection{Data Source}

The sources of the parameter values contained in the data files on the CD-ROM are:

\begin{tabular}{|c|c|}
\hline Column Name & Data Source \\
\hline SITE NAME & [Assigned by BORIS.] \\
\hline SUB_SITE & [Assigned by BORIS.] \\
\hline DATE_OBS & [Supplied by Investigator.] \\
\hline TIME_OBS & [Supplied by Investigator.] \\
\hline SENSIBLE_HEAT_FLUX_ABV_CNPY & [Solent sonic anemometer] \\
\hline LATENT_HEAT_FLUX_ABV_CNPY & [ IRGA ] \\
\hline NET_RAD_ABV_CNPY & [Net radiometer] \\
\hline SOIL_HEAT_FLUX_3CM_1 & [soil heat flux plate] \\
\hline SOIL_HEAT_FLUX_3CM_4 & [soil heat flux plate] \\
\hline SOIL_HEAT_FLUX_3 $3 \mathrm{CM}^{-}{ }^{-} 6$ & [soil heat flux plate] \\
\hline SOIL_HEAT_FLUX_3CM_7 & [soil heat flux plate] \\
\hline SOIL_HEAT_FLUX_3CM_8 & [soil heat flux plate] \\
\hline SOIL_HEAT_FLUX_3CM_9 & [soil heat flux plate] \\
\hline SOIL_HEAT_FLUX_8CM & [soil heat flux plate] \\
\hline CO2_FLUX_ABV_CNPY & [ IRGA ] \\
\hline $\mathrm{CO} 2$ CONC_ABV_CNPY & [ IRGA] \\
\hline $\mathrm{CO} 2{ }^{-} \mathrm{CONC}_{-} 39 \mathrm{M}$ & [ IRGA ] \\
\hline $\mathrm{CO} 2$ CONC_28M & [ IRGA ] \\
\hline $\mathrm{CO}_{2}{ }_{-} \mathrm{CONC}-22 \mathrm{M}$ & [ IRGA] \\
\hline $\mathrm{CO}^{-}{ }_{-} \mathrm{CONC}_{-} 18 \mathrm{M}$ & [ IRGA ] \\
\hline $\mathrm{CO} 2 \_\mathrm{CONC} \_10 \mathrm{M}$ & [ IRGA ] \\
\hline $\mathrm{CO} 2$ CONC_4M & [ IRGA ] \\
\hline $\mathrm{CO}_{2}{ }_{-} \mathrm{CONC}^{-} 2 \mathrm{M}$ & [ IRGA] \\
\hline $\mathrm{CO}^{-}{ }_{-} \mathrm{CONC}-50 \mathrm{CM}$ & [ IRGA ] \\
\hline BOWEN_RATIO_ABV_CNPY & [Supplied by Investigator.] \\
\hline KINEM_MOMENT_FLUXX_ABV_CNPY & [Solent sonic anemometer] \\
\hline DOWN_PPFD_ABV_CNPY & [quantum sensor] \\
\hline $\mathrm{UP} \_\mathrm{PPFD} \overline{\mathrm{ABV}} \_\mathrm{CN} \mathrm{PY}$ & [quantum sensor] \\
\hline$W I \overline{N D} \_D I \bar{R} \_A B \bar{V} \_$CNPY & [vane propeller anemometer] \\
\hline WIND_SPEED_ABV_CNPY & [vane propeller anemometer] \\
\hline FRICTION_VEL_ABBV_CNPY & [Solent sonic anemometer] \\
\hline MEAN_U_WIND_SPEED & [Solent sonic anemometer] \\
\hline VAR_W_WIND_SPEED & [Solent sonic anemometer] \\
\hline $\mathrm{H} 2 \mathrm{O}_{-} \mathrm{CONC} \_\mathrm{AB} \mathrm{B} \_\mathrm{CNPY}$ & [krypton hygrometer] \\
\hline $\mathrm{H} 2 \mathrm{O}_{-} \mathrm{CONC}_{-} 39 \mathrm{M}$ & [ IRGA ] \\
\hline $\mathrm{H} 2 \mathrm{O}_{-} \mathrm{CONC} \_28 \mathrm{M}$ & [ IRGA ] \\
\hline $\mathrm{H} 2 \mathrm{O} \_\mathrm{CONC} \_22 \mathrm{M}$ & [ IRGA ] \\
\hline $\mathrm{H} 2 \mathrm{O}_{-} \mathrm{CONC} \_18 \mathrm{M}$ & [ IRGA ] \\
\hline $\mathrm{H} 2 \mathrm{O}^{-} \mathrm{CONC}-10 \mathrm{M}$ & [ IRGA] \\
\hline $\mathrm{H} 2 \mathrm{O} \_\mathrm{CONC} \_4 \mathrm{M}$ & [ IRGA ] \\
\hline $\mathrm{H} 2 \mathrm{O} \_\mathrm{CONC} \_2 \mathrm{M}$ & [ IRGA] \\
\hline $\mathrm{H} 2 \mathrm{O}_{-} \mathrm{CONC}-50 \mathrm{CM}$ & [ IRGA ] \\
\hline AIR_TEMP_ABV_CNPY & [thermometer] \\
\hline AIR_TEMP_ABV_CNPY_2 & [thermometer] \\
\hline SOLENT_AIR_TEMP_ABV_CNPY & [Solent sonic anemometer] \\
\hline SOIL_TEMP_ $2 \overline{C M}$ & [thermocouple] \\
\hline SOIL_TEMP_5CM & [thermocouple] \\
\hline SOIL_TEMP_10CM & [thermocouple] \\
\hline SOIL_TEMP_20CM & [thermocouple] \\
\hline
\end{tabular}




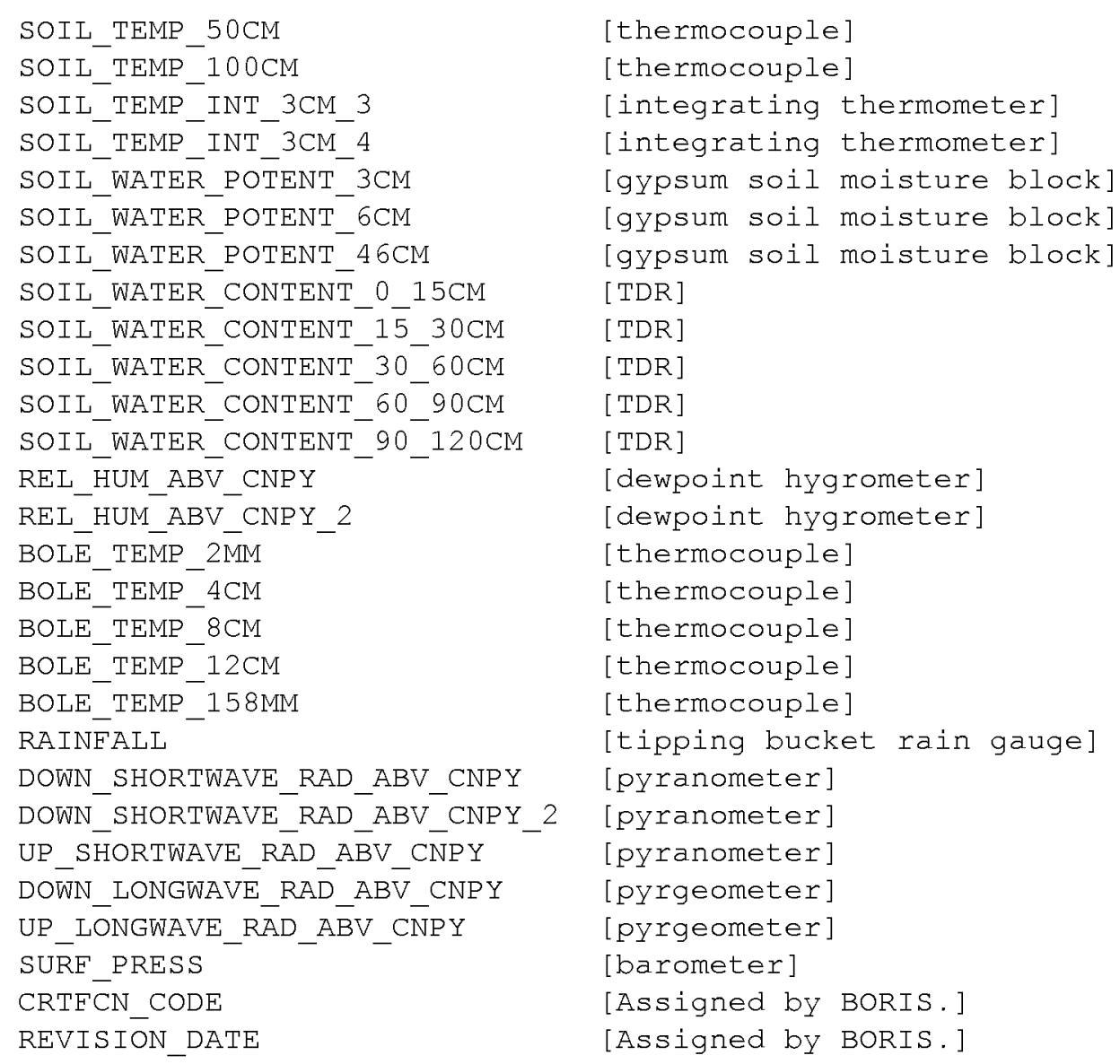

\subsubsection{Data Range}

The following table gives information about the parameter values found in the data files on the CD-ROM.

\begin{tabular}{|c|c|c|c|c|c|c|}
\hline Column Name & $\begin{array}{l}\text { Minimum } \\
\text { Data } \\
\text { Value }\end{array}$ & $\begin{array}{l}\text { Maximum } \\
\text { Data } \\
\text { Value }\end{array}$ & $\begin{array}{l}\text { Missng } \\
\text { Data } \\
\text { Value }\end{array}$ & $\begin{array}{l}\text { Unrel } \\
\text { Data } \\
\text { Value }\end{array}$ & $\begin{array}{l}\text { Below } \\
\text { Detect } \\
\text { Limit }\end{array}$ & $\begin{array}{l}\text { Data } \\
\text { Not } \\
\text { Cllctd }\end{array}$ \\
\hline SITE_NAME & SSA-9OA-FLXTR & SSA-9OA-FLXTR & None & None & None & None \\
\hline SUB_SITE & 9TF01-FLX01 & 9TF01-FLX01 & None & None & None & None \\
\hline DATE_OBS & $01-\mathrm{APR}-96$ & $30-\mathrm{DEC}-96$ & None & None & None & None \\
\hline TIME_OBS & 0 & 2330 & None & None & None & None \\
\hline $\begin{array}{l}\text { SENSIBLE_HEAT_FLUX_- } \\
\text { ABV_CNPY }\end{array}$ & -161.03 & 696.11 & -999 & None & None & None \\
\hline $\begin{array}{l}\text { LATENT_HEAT_FLUX_ABV } \\
\text { CNPY }\end{array}$ & -17.75 & 545.3 & -999 & None & None & None \\
\hline NET_RAD_ABV_CNPY & -85.387 & 833.85 & -999 & None & None & None \\
\hline SOIL_HEAT_FLUX_3CM_1 & -9.29 & 52.31 & -999 & None & None & None \\
\hline SOIL_HEAT_FLUX_3CM_4 & -20.37 & 52.01 & -999 & None & None & None \\
\hline SOIL_HEAT_FLUX_3CM_6 & -23.83 & 64.07 & -999 & None & None & None \\
\hline SOIL_HEAT_FLUX_3CM_7 & -18.32 & 52.69 & -999 & None & None & None \\
\hline SOIL_HEAT_FLUX_3CM_ 8 & -18.24 & 48.1 & -999 & None & None & None \\
\hline SOIL_HEAT_FLUX_3CM_9 & -31.5 & 29.26 & -999 & None & None & None \\
\hline SOIL_HEAT_FLUX_8CM & -10.45 & 47.37 & -999 & None & None & None \\
\hline CO2_FLUX_ABV_CNPY & -35.289 & 26.052 & -999 & None & None & None \\
\hline $\mathrm{CO} 2$ CONC_ABV_CNPY & 323.91 & 402.07 & -999 & None & None & None \\
\hline
\end{tabular}




\begin{tabular}{|c|c|c|c|c|c|c|}
\hline CO2_CONC_39M & -34.642 & 32.327 & -999 & None & None & None \\
\hline $\mathrm{CO} 2$ CONC_28M & 25.895 & 103.71 & -999 & None & None & None \\
\hline $\mathrm{CO} 2$ CONC_22M & -38.455 & 32.148 & -999 & None & None & None \\
\hline $\mathrm{CO} 2$ CONC_18M & 32.646 & 104.55 & -999 & None & None & None \\
\hline $\mathrm{CO} 2$ CONC_1OM & 324.8 & 403.34 & -999 & None & None & None \\
\hline $\mathrm{CO} 2$ CONC_4M & 324.63 & 419.14 & -999 & None & None & None \\
\hline $\mathrm{CO} 2$ CONC_2M & 321.16 & 416.14 & -999 & None & None & None \\
\hline $\mathrm{CO} 2$ CONC_50CM & 320.09 & 413.04 & -999 & None & None & None \\
\hline BOWEN_RATIO_ABV_CNPY & -4 & 4 & -999 & None & None & None \\
\hline $\begin{array}{l}\text { KINEM_MOMENT_FLUX_ } \\
\text { ABV_CNNPY }\end{array}$ & -2.65 & .144 & -999 & None & None & None \\
\hline DOWN_PPFD_ABV_CNPY & -.83782 & 2021.7 & -999 & None & None & None \\
\hline UP_PPFD_ABV_CNPY & -.94906 & 194.43 & -999 & None & None & None \\
\hline WIND_DIR_ABV_CNPY & 12.746 & 349.48 & -999 & None & None & None \\
\hline WIND_SPEED_ABV_CNPY & 0 & 8.994 & -999 & None & None & None \\
\hline $\begin{array}{l}\text { FRICTION_VEL_ABV_- } \\
\text { CNPY }\end{array}$ & .002 & 1.628 & -999 & None & None & None \\
\hline MEAN_U_WIND_SPEED & .022 & 9.673 & -999 & None & None & None \\
\hline VAR_W_WIND_SPEED & 0 & 3.681 & -999 & None & None & None \\
\hline $\mathrm{H} 20 \_\mathrm{CONC}$ ABBV_CNPY & -.215 & 22.144 & -999 & None & None & None \\
\hline H2O_CONC_39M & 320.55 & 516.64 & -999 & None & None & None \\
\hline $\mathrm{H} 2 \mathrm{O} \_\mathrm{CONC}-28 \mathrm{M}$ & 324.84 & 656.1 & -999 & None & None & None \\
\hline H2O_CONC_22M & 326.1 & 681.11 & -999 & None & None & None \\
\hline H2O_CONC_18M & 307.29 & 819.24 & -999 & None & None & None \\
\hline $\mathrm{H} 2 \mathrm{O} \_\mathrm{CONC}-10 \mathrm{M}$ & 2.871 & 27.459 & -999 & None & None & Blank \\
\hline $\mathrm{H} 2 \mathrm{O} \_\mathrm{CONC} 44 \mathrm{M}$ & 2.891 & 25.854 & -999 & None & None & Blank \\
\hline $\mathrm{H} 2 \mathrm{O} \_\mathrm{CONC}$ 2M & 2.896 & 26.526 & -999 & None & None & Blank \\
\hline $\mathrm{H} 20 \_\mathrm{CONC}$ 50 CM & 2.909 & 26.307 & -999 & None & None & Blank \\
\hline AIR_TEMP_ABV_CNPY & -34.451 & 31.492 & -999 & None & None & None \\
\hline AIR_TEMP_ABV_CNPY_2 & -33.378 & 30.343 & -999 & None & None & None \\
\hline $\begin{array}{l}\text { SOLENT_AIR_TEMP_ABV } \\
\text { CNPY }\end{array}$ & -34.207 & 32.67 & -999 & None & None & None \\
\hline SOIL_TEMP_2CM & -2.9 & 17.64 & -999 & None & None & None \\
\hline SOIL_TEMP_5CM & -2.341 & 15.495 & -999 & None & None & None \\
\hline SOIL_TEMP_10CM & -2.117 & 14.838 & -999 & None & None & None \\
\hline SOIL_TEMP_20CM & -1.584 & 13.454 & -999 & None & None & None \\
\hline SOIL_TEMP_50CM & -.602 & 11.791 & -999 & None & None & None \\
\hline SOIL_TEMP_100CM & .223 & 10.241 & -999 & None & None & None \\
\hline SOIL_TEMP_INT_3CM_3 & -6.096 & 20.6 & -999 & None & None & None \\
\hline SOIL_TEMP_INT_3CM_4 & -2.103 & 21.48 & -999 & None & None & None \\
\hline $\begin{array}{l}\text { SOIL_WATER_POTENT_ } \\
\text { 3CM }\end{array}$ & -1.3 & -.003 & -999 & None & None & None \\
\hline $\begin{array}{l}\text { SOIL_WATER_POTENT_ } \\
6 \mathrm{CM}\end{array}$ & -1.3 & -.006 & -999 & None & None & None \\
\hline $\begin{array}{l}\text { SOIL_WATER_POTENT_ } \\
46 \mathrm{CM}\end{array}$ & -1.3 & -.015 & -999 & None & None & None \\
\hline $\begin{array}{l}\text { SOIL_WATER_CONTENT_0 } \\
-15 \mathrm{CM}\end{array}$ & .14 & .7 & -999 & None & None & None \\
\hline $\begin{array}{l}\text { SOIL_WATER_CONTENT_ } \\
15 \_30 \mathrm{CM}\end{array}$ & .08 & .46 & -999 & None & None & None \\
\hline $\begin{array}{l}\text { SOIL_WATER_CONTENT_ } \\
30 \_60 \mathrm{CM}\end{array}$ & .17 & .38 & -999 & None & None & None \\
\hline $\begin{array}{l}\text { SOIL_WATER_CONTENT_ } \\
60 \_90 \mathrm{CM}\end{array}$ & .2 & .37 & -999 & None & None & None \\
\hline
\end{tabular}




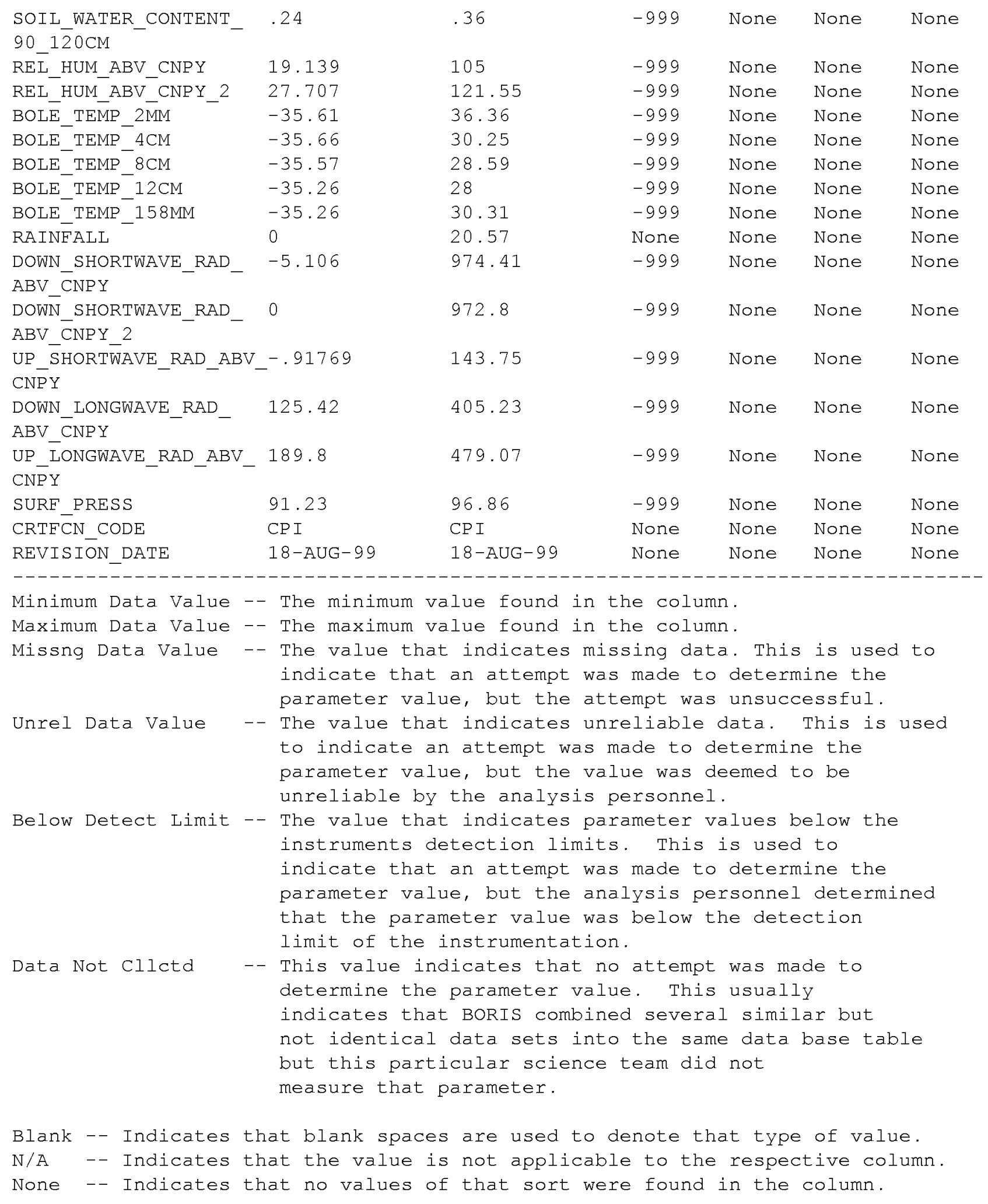




\subsection{Sample Data Record}

The following are wrapped versions of data record from a sample data file on the CD-ROM.

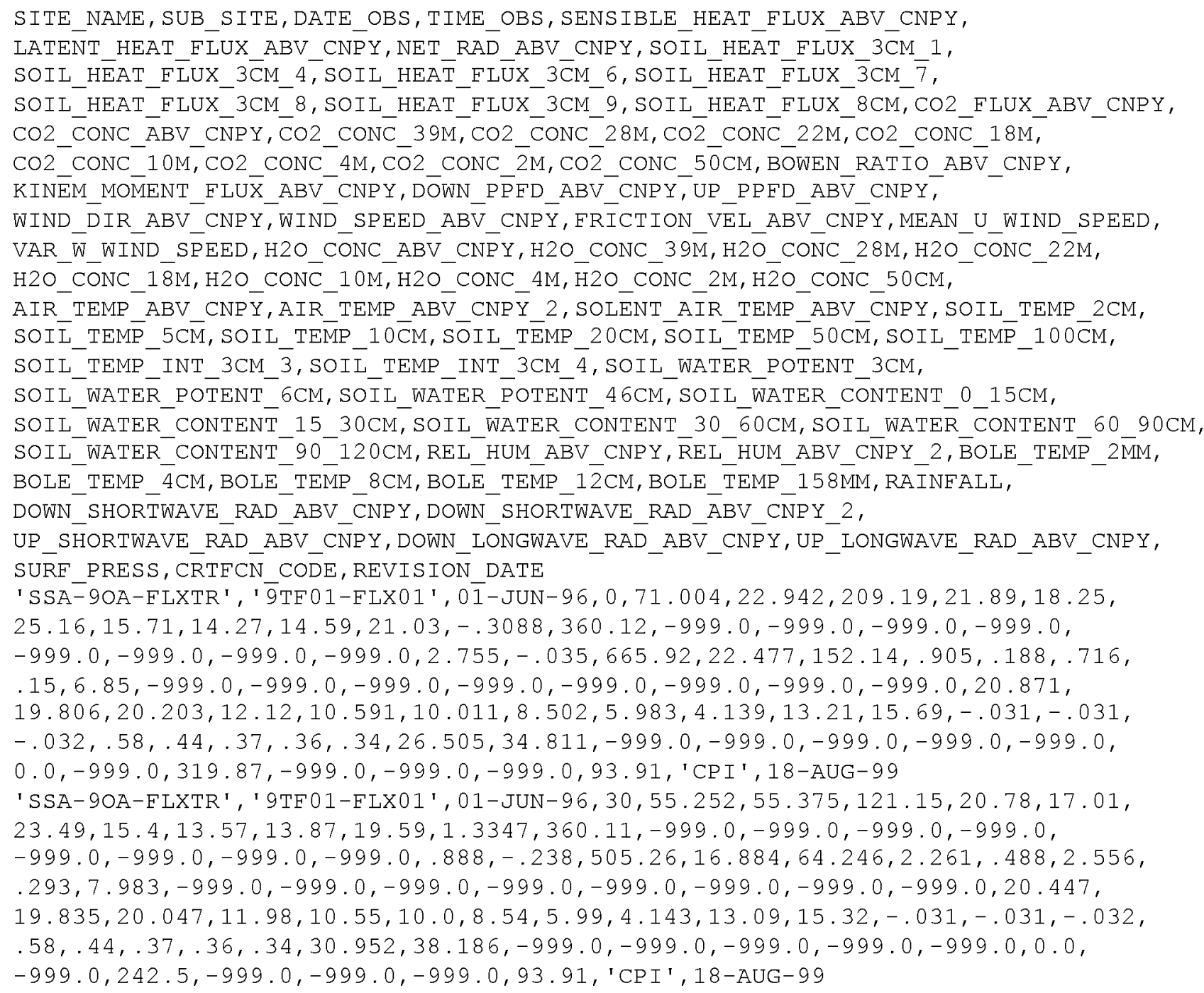

\section{Data Organization}

\subsection{Data Granularity}

The smallest unit of data tracked by the BOREAS Information System (BORIS) was data collected at a given site on a given date.

\subsection{Data Format}

The Compact Disk-Read-Only Memory (CD-ROM) files contain American Standard Code for Information Interchange (ASCII) numerical and character fields of varying length separated by commas. The character fields are enclosed with single apostrophe marks. There are no spaces between the fields.

Each data file on the CD-ROM has four header lines of Hyper-Text Markup Language (HTML) code at the top. When viewed with a Web browser, this code displays header information (data set title, location, date, acknowledgments, etc.) and a series of HTML links to associated data files and related data sets. Line 5 of each data file is a list of the column names, and line 6 and following lines contain the actual data. 


\section{Data Manipulations}

\subsection{Formulae}

\subsubsection{Derivation Techniques and Algorithms}

There are many equations and formulae used in the calculations of fluxes from the raw voltage signals. Readers are referred to the relevant references for details.

\subsection{Data Processing Sequence}

\subsubsection{Processing Steps}

Averages, variances, and covariances are calculated in real time, and coordinate rotation is applied on the half-hourly covariances and variances. WPL corrections were made to the water vapor and carbon dioxide fluxes measured using the closed-path LI-COR 6262 IRGA.

BORIS staff processed these data by:

- $\quad$ Reviewing the initial data files and loading them online for BOREAS team access.

- Designing relational data base tables to inventory and store the data.

- $\quad$ Loading the data into the relational data base tables.

- Working with the team to document the data set.

- $\quad$ Extracting the data into logical files.

\subsubsection{Processing Changes}

None.

\subsection{Calculations}

\subsubsection{Special Corrections/Adjustments}

WPL corrections were made to the water vapor and carbon dioxide fluxes measured using the closed-path LI-COR 6262 IRGA. Broadening correction was done, but not online (see Chen et al., 1998 , for summary of theory).

\subsubsection{Calculated Variables}

The Bowen ratio is the ratio of the sensible to latent heat flux.

\subsection{Graphs and Plots}

See Black et al., 1996; Chen et al., 1998; Blanken, 1997; and Yang, 1998.

\section{Errors}

\subsection{Sources of Error}

None given.

\subsection{Quality Assessment}

\subsubsection{Data Validation by Source}

Data were checked and flagged for various conditions in the original data base at UBC (Z. Nesic). Relatively little data were missing in 4-m measurements in 1994 and 39-m measurements in 1996.

\subsubsection{Confidence Level/Accuracy Judgment}

None given. 


\subsubsection{Measurement Error for Parameters}

None given.

\subsubsection{Additional Quality Assessments}

None.

\subsubsection{Data Verification by Data Center}

Data were examined to check for spikes, values that are four standard deviations from the mean, long periods of constant values, and missing data.

\section{Notes}

\subsection{Limitations of the Data} None given.

\subsection{Known Problems with the Data}

The soil heat flux plates at plots 2, 3, and 5 did not collect any usable data.

\subsection{Usage Guidance}

Read this document carefully or contact Drs. T.A. Black and Z. Chen.

\subsection{Other Relevant Information}

None.

\section{Application of the Data Set}

These data are useful for the study of water, energy, and carbon exchange in a mature aspen forest.

\section{Future Modifications and Plans}

Data collection from the SSA-OA tower continued after 1996. Contact Dr. T.A. Black for information about these data.

\section{Software}

\subsection{Software Description}

None given.

\subsection{Software Access}

None given. 


\section{Data Access}

The SSA-OA tower flux, meteorological, and soil temperature data are available from the Earth Observing System Data and Information System (EOSDIS) Oak Ridge National Laboratory (ORNL) Distributed Active Archive Center (DAAC).

\subsection{Contact Information}

For BOREAS data and documentation please contact:

ORNL DAAC User Services

Oak Ridge National Laboratory

P.O. Box 2008 MS-6407

Oak Ridge, TN 37831-6407

Phone: (423) 241-3952

Fax: (423) 574-4665

E-mail: ornldaac@ornl.gov or ornl@eos.nasa.gov

\subsection{Data Center Identification}

Earth Observing System Data and Information System (EOSDIS) Oak Ridge National Laboratory (ORNL) Distributed Active Archive Center (DAAC) for Biogeochemical Dynamics http://www-eosdis.ornl.gov/.

\subsection{Procedures for Obtaining Data}

Users may obtain data directly through the ORNL DAAC online search and order system [http://www-eosdis.ornl.gov/] and the anonymous FTP site [ftp://www-eosdis.ornl.gov/data/] or by contacting User Services by electronic mail, telephone, fax, letter, or personal visit using the contact information in Section 15.1.

\subsection{Data Center Status/Plans}

The ORNL DAAC is the primary source for BOREAS field measurement, image, GIS, and hardcopy data products. The BOREAS CD-ROM and data referenced or listed in inventories on the CD-ROM are available from the ORNL DAAC.

\section{Output Products and Availability}

\subsection{Tape Products}

None.

\subsection{Film Products}

None.

\subsection{Other Products}

These data are available on the BOREAS CD-ROM series. 


\section{References}

\subsection{Platform/Sensor/Instrument/Data Processing Documentation}

None.

\subsection{Journal Articles and Study Reports}

Baldocchi, D.D. 1997. Flux footprints within and over forest canopy. Boundary-Layer Meteorology, $85,273-292$.

Black, T.A., G. den Hartog, H.H. Neumann, P.D. Blanken, P.C. Yang, C. Russell, and Z. Nesic. 1996. Annual cycle of water vapor and carbon dioxide fluxes in and above a boreal aspen forest.

Global Change Biology, 2, 101-111.

Blanken, P.D. 1997. Evaporation within and above a boreal aspen forest. Ph.D. Thesis of UBC, 79-84.

Chen, W.J., T.A. Black, P.C. Yang, A.G. Barr, H.H. Neumann, Z. Nesic, P.D. Blanken, M.D. Novak, J. Eley, R.J. Ketler, and R. Cuenca. 1998. Effects of climatic variability on the annual carbon sequestration by a boreal aspen forest. Global Change Biology (in press).

Fritschen, L.J. and L.W. Gay. 1979. Environmental Instrumentation. Springer-Verlag, Berlin, New York and Heidelberg.

Fuchs, M. and C.B. Tanner. 1968. Calibration and field tests of soil heat flux plates. Soil Science Society of America Proceedings, 32, 326-328.

Hook, W.R. and N.J.Livingston. 1996. Errors in converting time domain reflectometry measurements of propagation velocity to estimated of soil water content. Soil Sci. Soc. Amer. J., 59, 35-41.

Kaimal, J.C. and J.E. Gaynor. 1991. Another look at sonic thermometry. Boundary-Layer Meteorology, 56, 401-410.

Lee, X., T.A. Black, and M.D. Novak. 1994. Comparison of flux measurements with open-and closed-path gas analyzers above an agricultural field and a forest floor. Boundary-Layer Meteorology, $67,1995-202$.

Leuning, R. and K.M. King. 1992. Comparison of eddy covariance measurements of $\mathrm{CO}_{2}$ fluxes by open- and closed-path $\mathrm{CO}_{2}$ analyzers. Boundary-Layer Meteorology, 59, 297-311.

Newcomer, J., D. Landis, S. Conrad, S. Curd, K. Huemmrich, D. Knapp, A. Morrell, J. Nickeson, A. Papagno, D. Rinker, R. Strub, T. Twine, F. Hall, and P. Sellers, eds. 2000. Collected Data of The Boreal Ecosystem-Atmosphere Study. NASA. CD-ROM.

Pearcy, R.W., J. Ehleringer, H.A. Mooney, and P.W. Rundel. 1991. Plant physiological ecology: Field methods and instrumentation. Chapman and Hall, London and New York.

Schuepp P.H., M.Y. Leclerc, J.I. MacPerson, and R.L. Desjardins. 1990. Footprint prediction of scalar fluxes from analytical solutions of the diffusion equation. Boundary-Layer Meteorology, 50, 355-373.

Sellers, P. and F. Hall. 1994. Boreal Ecosystem-Atmosphere Study: Experiment Plan. Version 1994-3.0, NASA BOREAS Report (EXPLAN 94). 
Sellers, P. and F. Hall. 1996. Boreal Ecosystem-Atmosphere Study: Experiment Plan. Version 1996-2.0, NASA BOREAS Report (EXPLAN 96).

Sellers, P., F. Hall, and K.F. Huemmrich. 1996. Boreal Ecosystem-Atmosphere Study: 1994 Operations. NASA BOREAS Report (OPS DOC 94).

Sellers, P., F. Hall, and K.F. Huemmrich. 1997. Boreal Ecosystem-Atmosphere Study: 1996 Operations. NASA BOREAS Report (OPS DOC 96).

Sellers, P., F. Hall, H. Margolis, B. Kelly, D. Baldocchi, G. den Hartog, J. Cihlar, M.G. Ryan, B. Goodison, P. Crill, K.J. Ranson, D. Lettenmaier, and D.E. Wickland. 1995. The boreal ecosystem-atmosphere study (BOREAS): an overview and early results from the 1994 field year. Bulletin of the American Meteorological Society. 76(9):1549-1577.

Sellers, P.J., F.G. Hall, R.D. Kelly, A. Black, D. Baldocchi, J. Berry, M. Ryan, K.J. Ranson, P.M. Crill, D.P. Lettenmaier, H. Margolis, J. Cihlar, J. Newcomer, D. Fitzjarrald, P.G. Jarvis, S.T. Gower, D. Halliwell, D. Williams, B. Goodison, D.E. Wickland, and F.E. Guertin. 1997. BOREAS in 1997: Experiment Overview, Scientific Results and Future Directions. Journal of Geophysical Research 102(D24): 28,731-28,770.

Webb, E.K., G.I. Pearman, and R. Leuning. 1980. Correction of flux measurements for density effects due to heat and water vapor transfer. Quarterly Journal of the Royal Meteorological Society, $106,85-100$.

Yang, P.C. 1998. Carbon dioxide flux within and above a boreal aspen forest. Ph.D. thesis, University of British Columbia, Vancouver, Canada.

\subsection{Archive/DBMS Usage Documentation} None.

\section{Glossary of Terms}

None.

\section{List Of Acronyms}

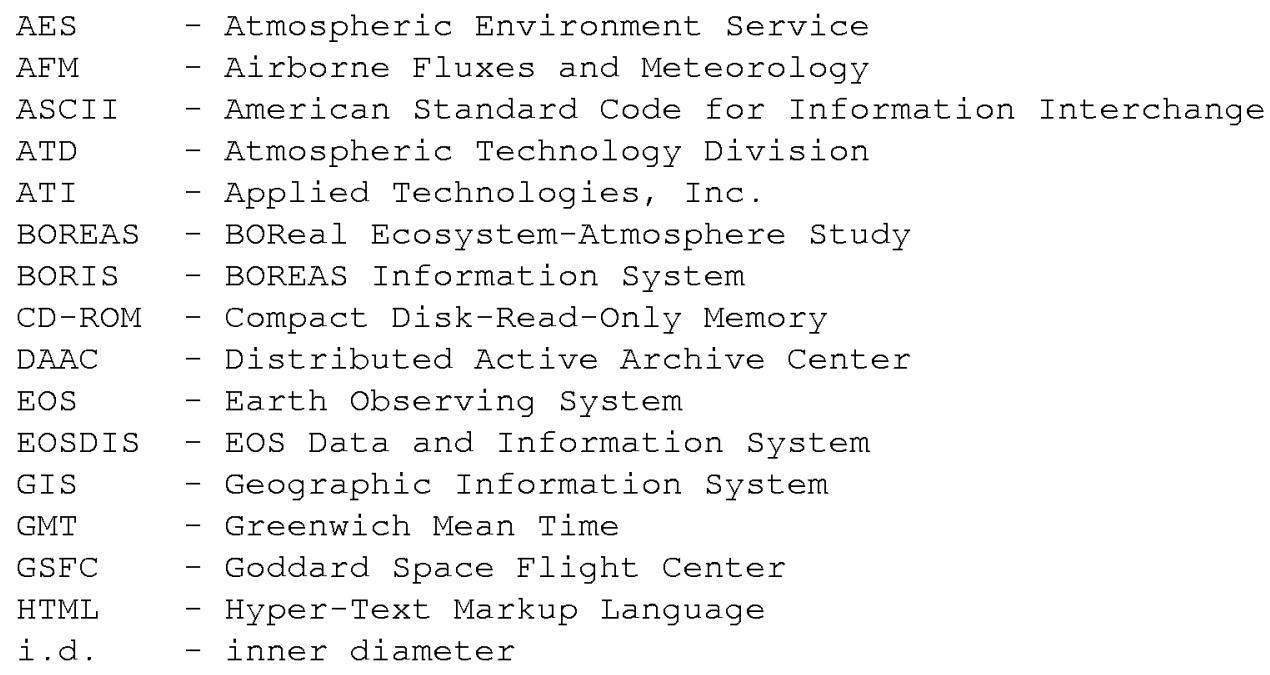




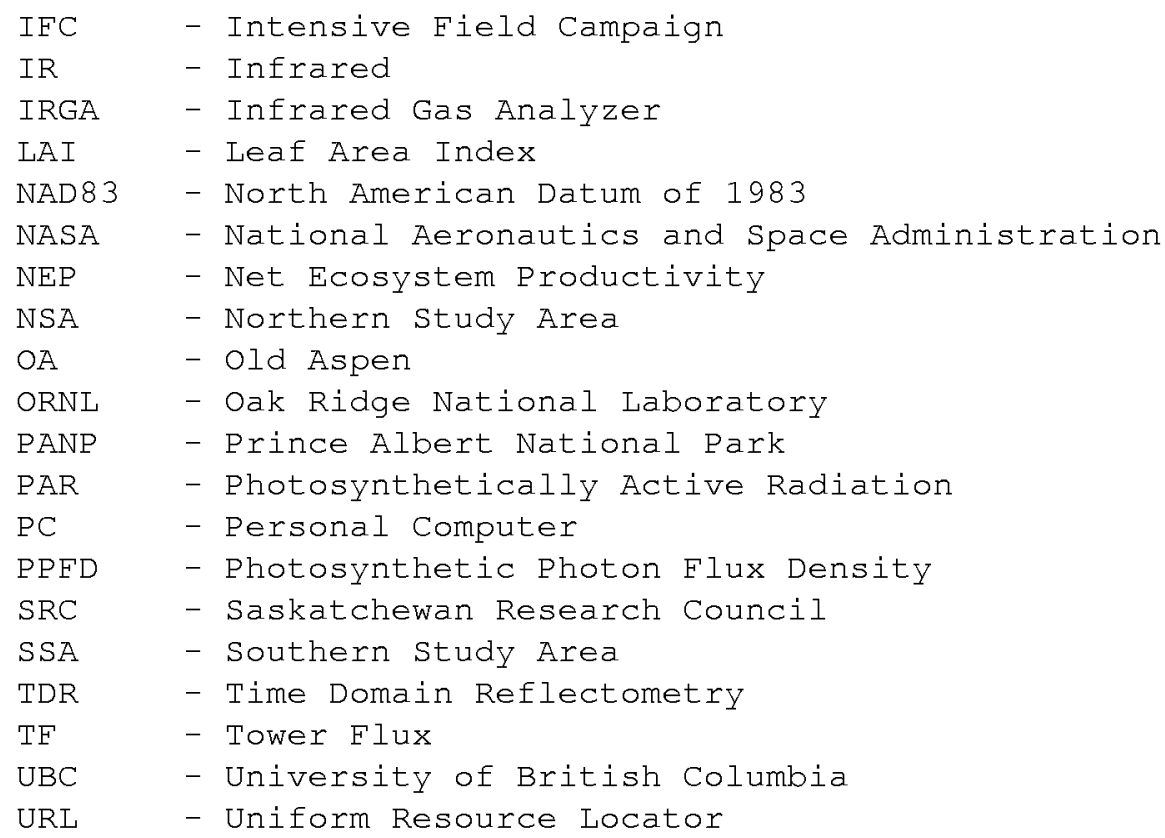

\section{Document Information}

20.1 Document Revision Date

Written: 04-Sep-1998

Last Updated: 03-Nov-1999

\subsection{Document Review Date(s)}

BORIS Review: 04-May-1999

Science Review:

\subsection{Document ID}

\subsection{Citation}

When using these data, please include the following acknowledgment as well as citations of relevant papers in Section 17.2:

Data were collected and processed by T.A. Black and Z. Nesic of the University of British Columbia.

If using data from the BOREAS CD-ROMs please also reference the data as:

Black, T.A. and Z. Nesic, "Boreal Forest Atmosphere Interactions: Exchanges of Energy, Water Vapor and Trace Gases." In Collected Data of The Boreal Ecosystem-Atmosphere Study. Eds. J.

Newcomer, D. Landis, S. Conrad, S. Curd, K. Huemmrich, D. Knapp, A. Morrell, J. Nickeson, A. Papagno, D. Rinker, R. Strub, T. Twine, F. Hall, and P. Sellers. CD-ROM. NASA, 2000.

Also, cite the BOREAS CD-ROM set as:

Newcomer, J., D. Landis, S. Conrad, S. Curd, K. Huemmrich, D. Knapp, A. Morrell, J.

Nickeson, A. Papagno, D. Rinker, R. Strub, T. Twine, F. Hall, and P. Sellers, eds. Collected Data of The Boreal Ecosystem-Atmosphere Study. NASA. CD-ROM. NASA, 2000.

\subsection{Document Curator}

\subsection{Document URL}


Public reporting burden for this collection of information is estimated to average 1 hour per response, including the time for reviewing instructions, searching existing data sources, gathering and maintaining the data needed, and completing and reviewing the collection of information. Send comments regarding this burden estimate or any other aspect of this collection of information including suggestions for reducing this burden, to Washington Headquarters Services, Directorate for Information Operations and Reports, 1215 Jefferson Davis Highway, Suite 1204, Arlington, VA 22202-4302, and to the Office of Management and Budget, Paperwork Reduction Project (0704-0188), Washington, DC 20503.

\begin{tabular}{|l|l|l}
\hline 1. AGENCY USE ONLY (Leave blank) & 2. REPORT DATE & 3. REPORT TYPE AND DATES COVERED
\end{tabular}

\begin{tabular}{l|l|l} 
October 2000 & Technical Memorandum
\end{tabular}

4. TITLE AND SUBTITLE

Technical Report Series on the Boreal Ecosystem-Atmosphere Study (BOREAS) BOREAS TF-1 SSA-OA Tower Flux, Meteorological, and Soil Temperature Data

\section{AUTHOR(S)}

T. Andrew Black, Z. Chen, and Zoran Nesic

Forrest G. Hall and Karl Huemmrich, Editors

\section{PERFORMING ORGANIZATION NAME(S) AND ADDRESS (ES)}

Goddard Space Flight Center

Greenbelt, Maryland 20771

5. FUNDING NUMBERS

923

RTOP: $923-462-33-01$

9. SPONSORING / MONITORING AGENCY NAME(S) AND ADDRESS (ES)

10. SPONSORING / MONITORING AGENCY REPORT NUMBER

National Aeronautics and Space Administration

Washington, DC 20546-0001

TM-2000-209891

Vol. 189

\section{SUPPLEMENTARY NOTES}

T.A. Black, Z. Chen, and Z. Nesic: University of British Columbia, Vancouver;

K. Huemmrich: University of Maryland, NASA Goddard Space Flight Center, Greenbelt, Maryland

12a. DISTRIBUTION / AVAILABILITY STATEMENT
Unclassified-Unlimited
Subject Category: 43
Report available from the NASA Center for AeroSpace Information,
7121 Standard Drive, Hanover, MD 21076-1320. (301) 621-0390.

12b. DISTRIBUTION CODE

13. ABSTRACT (Maximum 200 words)

The BOREAS TF-1 team collected energy, carbon dioxide, and momentum flux data above the canopy along with meteorological and soils data at the BOREAS SSA-OA site from mid-April to the end of the year for 1996. The data are available in tabular ASCII files.

14. SUBJECT TERMS
BOREAS, tower flux, meteorological data, soils data.
15. NUMBER OF PAGES

27

16. PRICE CODE

\begin{tabular}{l|c} 
17. SECURITY CLASSIFICATION & 18. SECURITY CLASSIFICATION \\
OF REPORT & OF THIS PAGE \\
Unclassified & Unclassified
\end{tabular}

Unclassified
19. SECURITY CLASSIFICATION OF ABSTRACT

Unclassified
20. LIMITATION OF ABSTRACT

$\mathrm{UL}$ 
